\title{
CONSTITUTIONAL APPROACHES TO PRIVATIZATION: AN INQUIRY INTO THE MAGNITUDE OF NEO-LIBERAL CONSTITUTIONALISM
}

\author{
DAVID SCHNEIDERMAN*
}

I

\section{INTRODUCTION}

It is common in the literature on globalization to find the claim that there is an "irreducible heterogeneity" in the world today-that there is, at present, an ongoing competition between different political cultures with no predetermined structure out of which emerges a predominant winner. Roland Robertson and Frank Lechner argue, for instance, that the global scene is "highly 'pluralistic"" and that there is a "proliferation" of competing definitions of the global situation. . Similarly, sociologist Martin Albrow writes that there is "no axial principle underlying global institutions." Rather, he argues, there is a pluralism reflecting "no theory of the greater good, simply the historic accumulation and interplay of national experiences and expertise coming to terms with each other."

This view fails to account adequately for the determinate rules and structures associated with "economic globalization," the ensemble of legal rules and structures for the promotion and protection of foreign investment. These rules and structures cumulatively attempt to fashion a global vision of economic policy, property rights, and constitutionalism that institutionalizes the political project called "neo-liberalism."

Copyright (C) 2001 by David Schneiderman

This article is also available at http://www.law.duke.edu/journals/63LCPSchneiderman.

* Faculty of Law, University of Toronto.

This paper was prepared initially for the conference "Public Perspectives on Privatization" held in Geneva, July 1999, and co-sponsored by Duke University, the University of Geneva, and the University of Alberta. It was later presented at a seminar at the Faculty of Law, University of Toronto. Professor Diego López-Medina of Universidad de los Andes and Professor Luz Nagle of Stetson University College of Law furnished important and timely advice, while Moira Gracey provided excellent research assistance and translation of some key texts. Many thanks to Professor Richard Bauman for the kind invitation to present at the Geneva conference and for the comments from audiences in Geneva and Toronto.

1. Roland Robertson \& Frank Lechner, Modernization, Globalization and the Problem of Culture in World-Systems Theory, 2 THEORY CULTURE \& SOC'Y 103, 111 (1985).

2. Martin Albrow, The Global AGE 125 (1996).

3. Id. 
In the post-1989 global scene, political alternatives seem to have narrowed in scope. The structures that influence political and economic life now are shaped by the global consensus that states must be made safe for trade and foreign investment. States are expected to remove regulatory restraints on the movement of capital, goods, and services, to divest themselves of publiclyowned enterprises - to privatize or denationalize real or financial assets-and to facilitate the private supply of certain goods and services by "contracting out" and "commercialization." A number of options to achieve privatization and denationalization are available to states, but two prevailing themes emerge, each corresponding to a different vision of constitutionalism. The first is the "state capitalist" model, designed to enhance the capacity for state control and public participation. ${ }^{5}$ The other is the "neo-liberal" model, which places legal limits on the state's regulatory capacity. ${ }^{6}$

This article asks whether constitutional rules in the state capitalist mode that redistribute property ownership more widely can survive the pressures generated by the neo-liberal model of constitutionalism. As a means of examining this question, this article takes up processes of privatization expressed in constitutional rules that grant ownership preference to employees of privatized state enterprises. Contemporary debates about the direction of constitutional design in an era of economic globalization are better understood in light of the interplay between these two contrasting models of constitutional thought. Contrary to Albrow's characterization, there appears to be a structural tilt to the global scene generating an emerging structure with a likely winner.

Privatization programs take a variety of forms. This article considers only those programs that concern the divestiture of state assets, or denationalization through the sale of shares or assets to employees and employee associations. It neither purports to discuss the assumed benefits of privately owned over publicly owned enterprises ${ }^{8}$ nor the benefits or pitfalls of this particular form of privatization over other methods, such as unrestricted sales to outsiders or equal-access vouchers. Among the alleged perils, it is feared that selling shares to employee "insiders" fails to bring new capital or new skills to divested companies," a case of "private benefits being had at public cost."

4. See D.G. McFetridge, The Economics of Privatization, C.D. Howe Institute Benefactors Lecture 2-6 (Oct. 22, 1997) (unpublished manuscript, on file with the author).

5. See infra text accompanying notes 17-25.

6. See infra text accompanying notes 11-16.

7. See Albrow, supra note 2, at 125.

8. See Carlos Vilas, Forward Back: Capitalist Restructuring, the State and the Working Class in Latin America, in WHITHER MARXISM? GLOBAL CRISES IN INTERNATIONAL PERSPECTIVE 123, 13133 (Bernd Magnus \& Stephen Cullenberg eds., 1995); JOSEPH E. STIGLITZ, WHITHER SOCIALISM? 179-81 (1994). Stiglitz argues that the case for privatization is political, not economic. See id. at 173. Government can "potentially almost always improve upon the market's resource allocation." Id. at 179.

9. See Cheryl W. Gray, In Search of Owners: Privatization and Corporate Governance in Transition Economies, 11 WORLD BANK RES. OBSERVER 179, 188 (1996).

10. Ronald A. Cass, Privatization: Politics, Law, and Theory, 71 MARQ. L. REV. 449, 514 (1988); see SEBASTIAN EDWARDS, CRISIS AND REFORM IN LATIN AMERICA 179 (1995). 
discussion, instead, proceeds on the assumption that enabling employee access to public property is a politically valid objective to achieve in the privatization context. The pertinent question is: Can this objective survive the regime of transnational rules for the promotion and protection of foreign investment?

\section{II}

\section{DIFFERING VISIONS OF CONSTITUTIONALISM}

In an era of pervasive economic globalization, state institutions are expected to subordinate political considerations to economic ones. Jacques Donzelot has remarked that this subordination signals a shift in the role of the state "from a guarantor of progress to a manager of destiny."11 The movement from the "social state" to "enabling state" requires a restructuring of state institutions, as well as the meta-rules that govern state institutional behavior. This change does not necessarily entail the abstention of the state, but rather activism of another sort: the creation of conditions to facilitate the smooth operation of the market. With social democracy's transformative enterprise seemingly extinct, current debates about the state's role turn on the axes of neo-liberalism (or economic liberalism) and state capitalism (or neo-social democracy). In this section, I discuss each of their respective constitutional images.

The dominant approach to constitutionalism is represented by the political project of neo-liberalism. This project advances the idea that the state should recede from the market and that limits should be placed on the redistributionist capacity of the state. Neo-liberalism is a project that disowns the compromises generated by tripartite corporatism and that treats citizens as undifferentiated consumers.

Associated with neo-liberalism is the school of constitutional thought concerned with designing institutions that place limits on the capacity of governments to intervene in the so-called "private" sphere. I have in mind here the group of theorists working within "constitutional political economy."12 This work is premised on the economic model of methodological individualismthat of the autonomous, self-interested, and rational actor. ${ }^{13}$

Constitutional political economists aim to secure the gains made in the post1989 international economic environment, such as the general tendency toward open markets and limited government, by constraining, through the force of constitutional and constitution-like limitations, the capacity of government to intervene in the market. ${ }^{14}$ These are proposals aimed at insulating "key aspects

11. Jacques Donzelot, The Mobilization of Society, in THE FOUCAULT EFFECT: STUDIES IN GOVERNMENTALITY 169, 176 (Graham Burchell et al. eds., 1991). See generally NiKolas Rose, POWERS OF FreEDOM: ReFrAming POLITICAL THOUght (1999) (discussing this shift in state functions from a neo-Foucaultian perspective).

12. James M. Buchanan, The Domain of Constitutional Political Economy, in THE ECONOMICS And THE ETHics Of CONSTITUTIONAL ORDER 3, 3-18 (1991).

13. See id.

14. See Stephen Gill, Globalisation, Market Civilisation, and Disciplinary Neoliberalism, 24 MiLlENNIUM: J. INT’L STUD. 399, 412 (1995). 
of the economy from the influence of politicians or the mass of citizens by imposing, internally and externally, 'binding constraints' on the conduct of fiscal, monetary, trade, and investment policies." 15

This enterprise has a transnational dimension. It is a model of constitutional government intended primarily to facilitate the free flow of goods, services, and persons unimpeded across the borders of nation-states-a model long promoted by the leading countries of the Organization for Economic Co-operation and Development ("OECD") and by affluent minorities within developing and less-developed countries. It takes shape via instruments intended to promote and protect foreign direct investment, such as the investment chapter of the North American Free Trade Agreement ("NAFTA"), bilateral investment treaties ("BITS"), and the draft Multilateral Agreement on Investment ("MAI").

The rules and structures of this program of reform resemble domestic constitutions: They bind governments over long periods of time to constitutionlike rules designed to protect the private property of individuals and firms against discriminatory treatment or takings of investment interests. These rules generate constitution-like entitlements legally enforceable before tribunals and courts. ${ }^{16}$

I want to contrast this neo-liberal agenda of constitutional reform with another stream of constitutional thought, one that has long been promoted by countries from the South. ${ }^{17}$ This is one that imagines a regime of constitutional rules and structures that facilitates the exercise of government power through state building and national enterprise. This approach recognizes that constitutions give expression to great national goals and projects-that constitutions are not just about limiting government action, but about enabling self-government. This is a view of the state approximating what Robert Cox calls "state capitalism," political economy. It is a model of institutional design that recognizes "the indispensable guiding role of the state in the development of the nation's productive forces." While state capitalism concedes the world market as the background of political choices, the project assumes that the state has a role to play in facilitating national competitiveness and in enabling the widest

15. $I d$.

16. See Stephen Clarkson, Somewhat Less Than Meets the Eye: NAFTA as Constitution, Address at the International Sociological Association Annual Meeting (July 27, 1998); David Schneiderman, The Constitutional Strictures of the Multilateral Agreement on Investment, 9 GOOD SOC'Y 90 (2000) [hereinafter Schneiderman, Constitutional Strictures]; David Schneiderman, NAFTA's Takings Rule: American Constitutionalism Comes to Canada, 46 U. TORONTO L.J. 499 (1996) [hereinafter Schneiderman, NAFTA's Takings Rule.].

17. For a discussion of the South as metaphor, see BOAVENTURA DE SOUSA SANTOS, TOWARD A New COMmon SENSE: LAw, SCIENCE AND POLITICS IN THE PARAdigmatic TRANSITION 506-18 (1995).

18. Robert W. Cox, The Global Political Economy and Social Choice, in APPROACHES TO WORLD ORDER 191, 201 (Robert W. Cox \& Timothy J. Sinclair eds., 1996).

19. Id. at 201. 
distribution of wealth across the social strata of society. ${ }^{20}$ When it takes a more "radical form," writes Cox, state capitalism tends "toward the prospect of internal socialism sustained by capitalist success in world-market competition." 21

The state-capitalist approach to constitutionalism can take shape through various models of constitutional design, but two come primarily to mind. The first model places no substantive limits on government intervention in the market. A.V. Dicey's description of English constitutional dogma in 1885 approximates this design. According to Dicey, Parliament was supreme: It could "make or unmake any law whatever," subject to the individual rights secured by what Dicey coined "the rule of law." 22 The second model facilitating energetic government is one that specifically articulates in constitutional language the capacity of the state to intervene in the market. Latin American constitutionalism best exemplifies this use of constitutionalism for the purpose of state building.

Latin American constitutions have committed governments to certain projects, such as mandating nationalization or management of key economic sectors, that bind successive governments to the maintenance of national goals and objectives. ${ }^{23}$ Constitutional rules may expressly enable state intervention in the market to redistribute wealth through rules permitting the expropriation or nationalization of property, subject, for instance, to the provision of "appropriate" compensation. ${ }^{24}$ This type of constitutional project also protects national political power from the external pressures generated by foreign economic power. Indeed, the Latin American constitutional experience of the twentieth century suggests that the international economic environment has long been an influence on constitutional design. ${ }^{25}$

In the 1990s, state capitalism fell into disfavor. The countries of Latin America mostly abandoned the constitutional design mandating public control over the economy or enabling nationalization of key economic sectors. Only a residue of these rules remains, and one of the objectives of this article is to identify this residue in the new 1991 Colombian Constitution. The key object of the article is to track challenges to the state-capitalist form of constitutional design as it confronts the neo-liberal model - a model of constitutional design that is taking shape both inside and outside of the state.

In some ways, the dysfunctional present and past of Colombian politics makes this constitution a poor subject of inquiry. Indeed, the Colombian case points to the insufficiency of constitutional rules as a mechanism for achieving

20. See id. at 202 .

21. Id.

22. A.V. Dicey, Introduction To The Study Of The LAw Of The Constitution 38, 183-84 (8th ed. 1915).

23. See infra text accompanying notes $34-35$.

24. See infra text accompanying notes 49-52.

25. See infra text accompanying notes $41-47$. 
social change. ${ }^{26}$ It is significant, though, that in 1991, Colombians massively overhauled their constitutional structure, abandoning the constitutional framework that had been in place since 1886 . Because this very recent exercise in constitution-making is under pressure from the neo-liberal model, we have an opportunity to track the confrontation between old and new constitutionalism. The Colombian constitutional experience proves to be representative of the larger Latin American constitutional experience of the 1980s and 1990s, in which the neo-liberal model has gained ascendance. ${ }^{27}$

III

\section{LATIN AMERICAN CONSTITUTIONALISM}

A number of pressures have generated this shift in emphasis from the public to the private, and from state building to state divestiture, in Latin American constitutionalism. $^{28}$ For one, the $1980 \mathrm{~s}$ debt crisis precipitated the adoption of structural adjustment programs under the active encouragement of the World Bank. ${ }^{29}$ A policy of selling off state enterprises has been a central plank in the Bank's strategy. ${ }^{30}$ Also, with the fall of the Soviet empire, there seemingly are fewer political options other than privatization available to those states wishing to improve the material conditions of their citizens and desiring to secure the political success of state managers. Moreover, numerous benefits are expected to fall upon states that take up programs of privatization, including increased foreign investment, overall efficiency gains, and technology transfers. ${ }^{31}$ At the very least, privatizing states can anticipate a huge financial windfall, the proceeds of which could be used to pay down the public debt. ${ }^{32}$ The shift in emphasis from public undertakings to private enterprise reflects the dominant discourse "subscribed to by corporate capital and most governments ... that competitiveness in the world economy is the ultimate criterion of policy.", The formation of public policy is subordinated to this goal of enhancing the structural competitiveness of the national economy.

26. But see Martha I. Morgan, Taking Machismo to Court: The Gender Jurisprudence of the Colombian Constitutional Court, 30 U. MiAmi InTER-Am L. REV. 253, 262 (1999) (arguing that the new Colombian Constitution "has changed Colombian views of constitutional rights and the role of the court in protecting those rights").

27. See infra text accompanying notes 34-39, 107-112, 174-84.

28. Sebastian Edwards identifies "the failure of the so-called heterodox programs in Argentina, Brazil, and Peru; the experience of the East Asian economies; the advice of the multilateral institutions; and the example of Chile" as factors contributing toward this "emerging consensus." EDWARDS, supra note 10 , at 48 .

29. See, e.g., THE WORLD BANK, WORLD DEVElOPMENT REPORT 1996: From Plan to MARKET 48-63 (1996).

30. See id.

31. See Alan Shipman, The Market Revolution And its Limits: A Price for EVERYTHING 410-12 (1999).

32. See id.

33. Robert W. Cox, Civil Society at the Turn of the Millenium: Prospects for an Alternative World Order, 25 REV. INT'L STUD. 3, 27 (1999). 
Since the late 1980s, Latin American countries have undertaken large-scale constitutional reform to relieve state agencies of the obligation of protecting the national "patrimony"-comprised of industries and public services considered vital to the future of the state, such as electric power, oil and gas development, and communication and transportation services. ${ }^{34}$ Article 27 of the 1917 Mexican Constitution, for instance, mandates state monopoly over the hydrocarbon and petroleum industries. ${ }^{35}$ Though these key sectors were exempted from NAFTA's scope, foreign investment rules have been relaxed to permit investment in the natural gas industry. ${ }^{36}$ Outside the parameters of NAFTA, it is reported that the Mexican government entered into "highly complex financing transactions" in order to evade constitutional restrictions on the oil industry. ${ }^{37}$ Other elements of Article 27 of the Mexican Constitution were amended in the lead-up to NAFTA, including provisions prohibiting the privatization of public commercial banks ${ }^{38}$ and rules protecting ejidos, communal land holdings that can now be broken up into individual parcels for the purpose of commercial enterprise..$^{39}$ These amendments precipitated the Zapatista armed rebellion in the Mexican state of Chiapas on New Year's Day 1994, the same day that NAFTA took effect. ${ }^{40}$

This movement amounts to an abandonment of the traditional Latin American model, traceable to the work of Argentinian jurist Carlos Calvo. ${ }^{41}$ Based on the dismal Latin American experience with interventionist international capital, Calvo argued that the countries of Latin America were entitled to the same degree of respect for their internal sovereignty as the United States of America and the countries of Europe. ${ }^{42}$ Among Calvo's precepts is the proposition that states should be free, within reason, from interference in the conduct of their domestic policy. ${ }^{43}$ From this premise, Calvo argued that foreign nationals could not lay claim to greater protection in their disputes with sovereign states than the citizens of those same countries. ${ }^{44}$ Foreign nationals who chose to establish themselves within the territorial

34. See Pierre Guislain, The Privatization Challenge: A Strategic, Legal, And INSTITUTIONAL ANALYSIS OF INTERNATIONAL EXPERIENCE 34-35 (1997).

35. See id.; Constitución Politica de los Estados Unidos Mexicanos [Constitution] art. 27 (Mex.) [hereinafter MEX. Const.].

36. See GUISLAIN, supra note 34, at 247.

37. Amy Chua, The Privatization-Nationalization Cycle: The Link Between Markets and Ethnicity in Developing Countries, 95 COLUM. L. REV. 223, 290 (1995).

38. See GUISLAIN, supra note 34 , at 35 .

39. See Jorge A. Vargas, NAFTA, The Chiapas Rebellion, and the Emergence of Mexican Ethnic Law, 25 CAL. W. INT'L. L.J. 1, 13 (1994).

40. See id. at 14.

41. See M. Charles Calvo, Le Droit International Theorique et Practique (2d ed. 1870). For an English language version of Calvo's doctrine, see EDWARD M. GALLAUDET, A MANUAL OF INTERNATIONAL LAW (1879).

42. See Donald R. Shea, The Calvo Clause: A Problem of Inter-American and INTERNATIONAL LAW AND DIPLOMACY 19 (1955); CALVO, supra note 41, at 261.

43. See SHEA, supra note 42, at 19; CALVO, supra note 41, at 194.

44. See SHEA, supra note 42, at 19; CALVO, supra note 41, at 369. 
confines of the host state-through direct investment, for instance-were entitled to no greater protection from state action than those nationals residing within the acting state. ${ }^{45}$ These precepts came to be reflected in the Mexican Constitution's Calvo Clause, which prohibits foreign investors from seeking the protection of their home state in any dispute with the Mexican host state. ${ }^{46}$ In some instances, a claim to foreign assistance can lead to the forfeiture of proprietary rights. ${ }^{47}$ Even these rules have been abandoned by the Mexican government in the lead-up to NAFTA through a series of non-constitutional and legislative edicts. ${ }^{48}$

A number of Latin American constitutions took up Calvo's doctrine. ${ }^{49}$ The 1991 Colombian Constitution draws on Calvo's precepts by declaring that "it is the duty of both citizens and of aliens in Colombia to obey the Constitution and the laws, and to respect and obey the authorities." ${ }^{50}$ Constitutional provisions concerning the expropriation of property give expression to this doctrine. ${ }^{51}$ One of the last vestiges of this takings rule could be found in the 1991 Colombian Constitution. The property clause authorized the legislative expropriation of property "for reasons of equity," without the payment of compensation, a determination that was not judicially reviewable. ${ }^{52}$

Constitutional declarations of exclusive state ownership and control also expressed this principle of the equality of states. ${ }^{53}$ Constitutional constraints could serve both the purpose of giving expression to important national objectives and of confining successive governments from bending too easily to the pressures of foreign investors and diplomatic overtures. ${ }^{54}$ The Calvo

45. See SHEA, supra note 42 , at 19.

46. See MeX. CONST. art. 27(I). Calvo's principles attracted international support in the 1970s, appearing in a variety of international resolutions, including the U.N. General Assembly Resolution of 1973-declaring the New International Economic Order-and the 1974 U.N. Charter of Economic Rights and Duties of States. Article 2 of the Charter declares that laws governing nationalization and expropriation of property are those of the nationalizing state and not those of international law. See Justine Daly, Has Mexico Crossed the Border on State Responsibility for Economic Injury to Aliens? Foreign Investment and the Calvo Clause in Mexico after the NAFTA., 25 ST. MARY'S L.J. 1147, 1186-87 (1994).

47. See Gloria L. Sandrino, The NAFTA Investment Chapter and Foreign Direct Investment in Mexico: A Third World Perspective, 27 VAND. J. TRANSNAT'L L. 259, 268 (1994). The Brazilian Constitution reserved mining exploration and production facilities to Brazilian-controlled firms. This has now been amended to permit foreign operations so long as the firm is established under Brazilian law and has its headquarters and management in Brazil. See Constituição Federal [C.F.] art. 176 (Braz.) [hereinafter BRAZ. CONST.]; GUISLAIN, supra note 34, at 36.

48. See GUISLAIN, supra note 34 , at 36 .

49. See Eduardo A. Wiesner, ANCOM: A New Attitude Toward Foreign Investment?, 24 U. MiAMI INTER-AM. L. REV. 435-65 (1993).

50. Constitución Política de la República de Colombia [Constitution] art. 4. (Colom.) [hereinafter COLOM. CONST.].

51. See id. art. 58.

52. Id.; see also infra text accompanying note 100 (concerning the recent amendment of this provision).

53. Though nationalization of material resources in Latin America, Amy Chua writes, often was precipitated by the "expropriation of political power ... from the class against which nationalization is directed." Chua, supra note 37, at 272.

54. See SHEA, supra note 42 , at 20. 
doctrine, though, never was acceptable to the United States and other European powers. ${ }^{55}$

\section{THE COLOMBIAN CONSTITUTION}

The Colombian Constitution is a modern text that aspires to secure important national social objectives but at the same time is encountering significant pressures to conform to new transnational norms. The Colombian model also provides an interesting case study in the insufficiency of constitutional guarantees to secure the social change necessary for peace and security. The inability to achieve these changes, however, lies beyond the scope of this paper. Instead, it focuses on the constitutional reforms of 1936 and 1991, intended to give effect to important objectives as they pertain to property rights and privatization.

\section{A. 1936 Reforms}

The reforms of 1936 have been portrayed as Colombia's "New Deal." The radical Liberal administration of President Alfonso López Pumarejo wrested control of government from the Conservatives who had held power for decades. $^{56}$ López instituted a variety of social reforms, including tax reform, agrarian reform, and the 1936 constitutional reforms, during a period known as the Revolución en marcha. ${ }^{57}$ Article 26 of the Colombian Constitution was amended to enshrine the notion that "property is a social function which implies obligations." ${ }^{58}$ It also provided that in the event of a conflict between private interests and laws passed for reasons of "public utility or social interest," the private must give way to the public. ${ }^{59}$

The 1936 constitutional reforms enabled the state to expropriate property for purposes of "public utility or social interest." This could be achieved under judicial supervision with the provision of prior compensation or, for reasons of equity, without compensation by a two-thirds majority vote of the Senate and House of Representatives. ${ }^{60}$

55. Great Britain was responsible for at least forty armed interventions in Latin America between 1820 and 1914. See Charles lipson, Standing Guard: Protecting Foreign Capital In The NinETEENTH AND TWENTIETH CENTURIES 54 (1985).

56. See Richard Stoller, Alfonso López Pumarejo and Liberal Radicalism in 1930s Colombia, $27 \mathrm{~J}$. LATIN AM. STUD. 367, 367 (1995).

57. See id.

58. COLOM. CONST. art. 26 (repealed 1991).

59. Id. art. 26.

60. See William Marion Gibson, The Constitutions Of Colombia 367 (1948).

Article 26: Private property and other rights legally acquired in accordance with the civil laws by natural or juridic persons shall be guaranteed, nor may they be disavowed by later laws. When the enforcement of a law passed for reasons of public utility or social interest conflicts with the rights of individuals, private interests must give way to the public or social interests.

Property is a social function which implies obligations. 
Recognizing that private ownership implies a degree of social obligationthat property serves a social function-is a conventional idea in post-realist legal thought. ${ }^{1}{ }^{2}$ The intellectual origins of this reform in Colombia often are traced back to the work of French constitutional theorist Léon Duguit. ${ }^{62}$ Duguit outlined a theory of the state familiar to British and American progressives of the late nineteenth and early twentieth centuries: that the state is merely a body of men issuing orders. ${ }^{63}$ The authority of the state is justified by the function it performs, and according to Duguit, that function was to provide for certain social needs. ${ }^{64}$ Private property was justifiable to the extent that it served and was limited by this social mission. ${ }^{65}$

Despite its seemingly foreign origins, Kenneth Karst argues that this approach to property comports well with Latin American understandings. ${ }^{66}$ The principle that property fulfills a social function, for instance, has doctrinal support in the notion that the underlying title to all lands lies in the state. ${ }^{67}$ This idea was given expression in Article 27 of the 1917 Mexican Constitution and Articles 165 and 166 of the Bolivian Constitution: All private property is contingent on a transfer of title from the "Nation"-the guardian of all lands and waters. ${ }^{68}$ Article 27 recognizes that all rights of ownership emanate from the state and, Karst writes, "properly depend[] for [their] continuance upon the satisfaction of community needs." ${ }^{69}$ It is entirely consistent, then, to ascribe social functions to property and social obligations to property holders. A number of Latin American constitutions recognize this social function: The Venezualan constitutional guarantee of the right to private property is subject to the "public benefit or the general interest," declares that the social function of property includes the requirements of the

\footnotetext{
For reasons of public utility or social interest, as defined by the legislature, property may Id. be expropriated by judicial decree with prior indemnification.

61. See Joseph William Singer \& Jack M. Beerman, The Social Origins of Property, 6 CAN. L.J. \& JURIS. 217 (1993).

62. See Kenneth Karst, Latin-American Land Reform: The Uses of Confiscation, 63 MICH. L. REV. 327, 346 (1964); Stoller, supra note 56, at 391. Inspiration also was drawn from the Mexican Constitution of 1917, the Weimar Constitution of 1919, and the Spanish Constitution of 1931. See LuIS CARlos SACHICA, CONSTITUCIONALISMO COLOMBiano 263 (1989). Excerpts from Duguit's influential 1911 lecture in Buenos Aires are reproduced in AlFREDO CONSTAIN, ElEMENTOS DE DERECHO CONSTITUCIONAL 253-58 (1959).

63. See Harold J. Laski, Note, A Note on M. Duguit, 31 HARV. L. REV. 186, 187-88 (1917-18).

64. See id.

65. See Leon Duguit, Manuel De Droit Constitutionnel 13, 295 (4th ed. 1923).

66. See Karst, supra note 62, at 356.

67. See id.

68. See Mex. Const. art. 27; Constitución Política del Estado [Constitution] arts. 165-66 (Bol.) [hereinafter BOL. Const.].

69. Karst, supra note 62 at 356.

70. Constitución DE LA República de Venezuela [Constitution] art. 99 (Venez.) [hereinafter VENEZ. CONST.].
} 
nation's general interest, security, public use, health, and environmental conservation. ${ }^{71}$

In the Colombian context, property as a social function also gives constitutional expression to the Lockean edict that land must not remain idle but must be utilized productively. ${ }^{72}$ Albert Hirschman, in his 1963 work on Colombian land reform, traces the lineages of this ideology in Colombian political culture. $^{73}$ The socially condoned practice of settling (or colonizing) the seemingly empty and unproductive lands of the interior of Colombia resulted in a highly inequitable concentration in the hands of large (hacienda) landowners. ${ }^{74}$ Legislation giving effect to the 1936 constitutional reform (Law 200) was consistent with this ideology of productivity. ${ }^{75}$ The law was intended to divest speculative property owners of their uncultivated rural lands by authorizing the expropriation of lands that remained uncultivated for more than ten years. ${ }^{76}$ Law 200, wrote Hirschman, "established the fundamental principle that a presumption of private property exists in favour of those who occupy the land and make 'economic use' of it."

As Hirschman shows, the agrarian reform movement of the 1930s and its successor program of the $1960 \mathrm{~s}^{78}$ made little "progress." constitutional reforms, which were seemingly radical, were never intended to be effective. Hirschman's 1963 study closed with the observation that the passage of progressive land reform laws in Colombia "may have been facilitated by the long tradition of issuing well-meaning and socially advanced laws and decrees which turn out to be ineffective because of enforcement or clever obstruction." ${ }^{\prime 80}$

71. See CONSTITUCión Política de la RepúbliCA de Chile [Constitution] art. 19, II 24 (Chile) [hereinafter CHILE CONST.]; Terence Daintith \& Monica Sah, Privatisation and the Economic Neutrality of the Constitution, 1993 PUB. L. 465, 474-75; Steven E. Hendrix, Property Law Innovation in Latin America With Recommendations, 18 B.C. INT'L \& COMP. L. REV. 1, 7-8 (1995).

72. See JOHN LOCKE, The Second Treatise of Government, in TWO TREATISES OF GOVERNMENT 296-97 (Peter Laslett ed., Cambridge Univ. Press, 1988) (1690).

73. See Albert O. Hirschman, Journeys Towards Progress: Studies Of Economic POLICY-MAKING IN LATIN AMERICA (1965).

74. See Alfonso López, Latifundismo and the Need for Agrarian Reform in Colombia, in AGRARIAN REFORM IN LATIN AMERICA 87 (T. Lynn Smith, ed. 1965).

75. See Hirschman, supra note 73, at 107-13 (discussing the Law 200 constitutional reform of 1936).

76. See id.

77. HiRSCHMAN, supra note 73 , at 150 .

78. See id. New land reform initiatives were undertaken in the 1960s following a plebiscite in 1957 affirming the constitutional reforms of 1936. Little progress was achieved. Property was more unequally distributed by 1970 than before; larger agricultural holdings occupied even more of the national territory. See Harvery F. Kline, Columbia: Building Democracy in the Midst of Violence and Drugs, in CONSTRUCTING DEMOCRATIC GOVERNANCE: LATIN AMERICA AND THE CARIBBEAN IN THE 1990s, PART III, at 20, 39 (Jorge I. Dominguez \& Abraham F. Lowenthal eds., 1996); CARLOS Felipe Jaramillo, Liberalization, CRisis \& Change In COlOmbian Agriculture 51-52 (1998). The Constitutional Assembly recalled the "repugnant corruption" of forced expropriations: It was "a great business" to expropriate and to be expropriated. See Colombian Constitutional Court Decision No. C-358/96 (1996) at 42 (on file with author).

79. Hirshman, supra note 73, at 197.

80. Id. at 211 . 
Other work on the period confirms these suspicions. ${ }^{81}$ There appears to have been no widespread belief in the 1930s that the solution to economic inequality lay in constitutional reform, or that the 1886 Constitution somehow impeded the achievement of effective social and economic change. ${ }^{82}$ The impulse for constitutional reform in 1936, in other words, was "primarily political rather than socioeconomic." 83

Though no meaningful land reform was realized, the 1936 constitutional changes enabled the state to undertake modest agrarian reform in the 1960s that impinged on property rights. ${ }^{84}$ The Colombian Constitutional Court considered one such challenge to the actions of the Instituto Colombiano de Reforma Agraria ("INCORA"), the body charged with expropriating land under the 1961 agrarian law. The institute was mildly activist: By 1963, INCORA had instigated 108 lawsuits seeking revocation of title or the invalidation of claims to land..$^{85}$ Property owners were compensated by the state at market value with the provision of government bonds redeemable at some future time. Property owners, however, alleged that the state had expropriated property without "prior indemnification." If the state bonds were not immediately realizable, it was argued that this did not satisfy the constitutional requirement of prior compensation in Article $26 .{ }^{87}$

In finding for the state, the Court reflected on the meaning of the social function of property: "The social function ... accentuated the subordination of ownership to community interests, to the point that the guarantee given in the Constitution in favor of property rights is conditioned on the extent to which the rights correspond to the needs of the community." 88 In light of this constitutional "prevalence of social interests over private ones, in all instances and circumstances," the Court found that the provision of compensation in the form of bonds satisfied the constitutional requirement of Article $26{ }^{89}$

Karst noted in 1964 that talk about social function largely was restricted to rural land. ${ }^{90}$ The "similar performance of social functions might, with equal reason," he wrote, "be demanded of other property." Constitution includes provisions for the privatization of public enterprise and, I argue, underlying these provisions is the principle that property serves social functions - the principle that property is subordinated to community interests.

81. See Stoller, supra note 56, at 393.

82. See id.

83. Id. at 393.

84. See T. Lynn Smith, Colombia: Social Structure and the Process Of Development 89 (1967)

85. See id.

86. Kenneth L. Karst \& KeIth S. Rosenn, LAW And DeVElopment in LATIN America 34849 (1975).

87. See id.

88. Id.

89. Id. at 348 .

90. See Karst, supra note 62, at 356.

91. Id. at 347. 


\section{B. 1991 Colombian Constitution}

Colombia was one of the few Latin American countries not to have experienced severe financial turmoil in the 1980s: Until recently, Colombia had low debt ratios and only moderate fiscal deficits. ${ }^{22}$ The relative success of the Colombian economy, however, has not spared successive governments from having to engage in some austerity initiatives, namely, International Monetary Fund-induced adjustment programs. ${ }^{93}$

Colombia's 1990 program of economic liberalization, Apertura, signaled its openness to foreign investment and commitment to a modest program of privatization. $^{94}$ According to the government's report to the World Trade Organization ("WTO") in 1996, "[t]he purpose of the privatization of public sector assets is to free the Government resources tied up in activities that could be carried out more efficiently by the private sector and to transfer them to sectors where Government intervention is essential, for example, education, health, justice and security." 95 Privatization, in other words, could increase revenue flows, reduce the deficit, and help to subsidize social reform. ${ }^{96}$

One of the catalysts for this program of economic and social change was the achievement of constitutional reform in 1991. This task was undertaken by a multiparty constitutional assembly, composed of seventy elected delegates widely representative of various constituencies in Colombian political life, including the Conservative and Liberal parties, labor, indigenous peoples, and four representatives of demobilized guerilla groups, including the M-19 guerilla movement. ${ }^{97}$ The constitutional assembly has been described as the "first body in Colombia to work by seeking consensus" and its successful negotiation of a new constitution for Colombia as "stunning." It was hoped that the new constitution would provide a framework for neutralizing the major sources of

92. See Jose Antonio Ocampo, Crisis and Economic Policy in Colombia, 1980-85, in LATIN AMERICAN DEBT AND THE AdJUSTMENT CRISIS 239, 257 (Rosemary Thorp \& Laurence Whitehead eds., 1987).

93. In 1984, Colombia's adjustment program "not only involved an orthodox macroeconomic programme under IMF surveillance, but also World Bank interference in sectoral, particularly commercial, policies." Id. In December 1999, Colombia entered into a \$2.7 billion (U.S.) loan agreement with the IMF, conditioned on increasing privatizations. See Recovery, of Sorts, ECONOMIST, Apr. 22, 2000, at 32.

94. See David J. Pascuzzi, International Trade and Foreign Investment in Colombia: A Sound Economic Policy Amidst Crisis, 9 FLA. J. INT'L L. 443, 449-50 (1994).

95. Colombia, Trade PoL'y Rev. (Gen. Agreement on Tariffs and Trade, Geneva, Switz.) 1996, at 166 .

96. See Pascuzzi, supra note 94 , at 468.

97. See Donald T. Fox \& Anne Stetson, The 1991 Constitutional Reform: Prospects for Democracy and the Rule of Law in Colombia, 24 CASE W. RES. J. INT'L. L. 139, 145 (1992).

98. Id.; see also William C. Banks \& Edgar Alvarez, The New Colombian Constitution: Democratic Victory or Popular Surrender?, 23 U. MiAmI InTER-AM. L. REV. 39, 45 (1991). The two remaining major armed resistance movements, the Colombian Revolutionary Armed Forces ("FARC") and the National Liberation Army ("ELN"), both refused to participate. See The National Organization of Indigenous Peoples of Columbia ("ONIC"), Participation of Columbian Indigenous Peoples in the Constitutional Reform of 1991, in ABORIGINAL PeOPLes 66, 72-73 (Marie Leger ed. \& Arnold Bennett trans., 1994). It is said that the guerilla war reduces GDP by at least two percent per year. See David Swafford, Halo of Hope, LATIN Fin., Mar. 1999, at 45. 
corruption and instability in Colombia, including continued armed resistance by Marxist guerillas and political violence instigated by the drug traffic in cocaine.

The 1991 constitution, then, amounts to a remarkable achievement by a fractious assembly in a country riven by violence and instability in all sectors of political life. The idea of estado social de derecho-an admixture of social state and rule of law-gives expression to the role of the state captured in the new constitution. $^{99}$ The text guarantees a variety of social and economic rights, in addition to the recognition of indigenous self-government. While the constitution gives general protection to private property, the text also envisions the democratization of property. ${ }^{100}$ In Article 60, the constitution declares that the state "will promote access to property." It also is "the duty of the state to promote the gradual access of agricultural workers to landed property in individual or associational form." ${ }^{102}$ Aboriginal communal land rights are recognized, ${ }^{103}$ and these lands are "inalienable, impresecriptible, and not subject to seizure." ${ }^{104}$ Contrary to the seemingly universal tendencies in international investment law, the constitution also permitted the expropriation of property without the provision of compensation. ${ }^{105}$ According to the Colombian Constitutional Court, the specific assignment of the estado social de derecho "consists in making real the social function of property." 106

99. See Manuel José Cepeda, Democracy, State and Society in the 1991 Constitution: The Role of the Constitutional Court, in Colombia: The Politics of ReForming the STATE 71, 86 (Eduardo Posada-Carbó ed., 1998).

100. See COLOM. CONST. art. 58:

Private property and other rights acquired in accordance with civil laws may not be ignored or infringed upon by subsequent laws. When in the application of a law passed on account of public utility or social interest and recognized as essential a conflict should occur about the rights of individuals, the private interest will have to give precedence to the public or social interest.

Property is a social function which implies obligations. As such an ecological function is inherent to it.

The state will protect and promote associational and collective forms of property.

Because of public necessity or social interest defined by the legislative, expropriation will be possible by means of a judicial determination and prior indemnification. The latter will be determined in consultation with the interests of the community and of the affected party. In cases determined by the legislative, said expropriations may be pursued by administrative means, subject to subsequent contentious administrative action at law, including with respect to price.

Still, the legislative, for reasons of equity, may determine those cases in which there is no ground for indemnification through an affirmative vote of the absolute majority vote of the members of both chambers.

Reasons of equity, as well as motives of public necessity or social interest invoked by the legislative, will not be judicially reviewable.

Id. The last two paragraphs were repealed by Acto Legislativo 1/99 (Aug. 4, 1999). See discussion infra Part IV.)

101. ColOM. CONST. art. 60.

102. Id. art. 64 .

103. See id. art. 329.

104. Id. art. 63 .

105. See id. art. 58 .

106. Colombian Constitutional Court Decision No. C-037/94, § 2.2 (on file with author). 
Nonetheless, a program of privatization of public sector assets and responsibilities is expressly contemplated. The 1991 constitution endorses the internationalization of economic relations ${ }^{107}$ and permits the congress to authorize the government to "sell national assets." "While "public health and environmental protection" are declared to be "public services for which the state is responsible," the constitution permits "private entities ... to exercise oversight and control over them." 109 Social security is a guaranteed "irrevocable right" that "may be provided by public or private entities." is obliged to promote "access to property," when a state enterprise is privatized, it is obliged to offer employees, trade unions, pension funds, and cooperatives (sector solidario) shares at a minimum price and under special credit conditions. ${ }^{111}$ Privatization in the Colombian Constitution, then, aspires to disperse property ownership to a wide stratum of the population rather than concentrating it in the hands of foreign investors or the already affluent. ${ }^{112}$

The Constitutional Court has halted the privatization of financial institutions because the scheme failed to comply with the requirements of Article $60 .{ }^{113}$ As the share offering to the solidarity sector was limited to fifteen percent, and as preferential conditions also were attached to offers to current shareholders, the scheme violated the constitutional commitment to the "democratization" of public property. ${ }^{114}$ Nevertheless, by 1996, the Colombian government had privatized approximately 100 state-owned or -controlled entities, ${ }^{115}$ including more than six banks, savings and loan corporations, the

107. See COLOM. CONST. art. 277.

108. Id. art. 150.9.

109. Id. art. 49.

110. Id. art. 48 .

111. See Constitutional Court Decision No. C-037/94, § 3 (on file with author); see also COLOM. CONST. art. 60:

When the state sells its interest in an enterprise, it will take measures promoting democratization of the ownership of its shares and will offer its workers or the collective and worker's organizations special terms to make it possible for them to accede to the said Id. proprietary shares.

112. According to the Colombian Constitutional Court, Article 60 is designed to prevent the privatization procedure followed "in many countries" in which privatization "is converted into the transfer of public property, for a fraction of its worth, to the richest sectors of society." Colombian Constitutional Court Decision No. C-452/95 (on file with author). Similar provisions can be found in the 1992 Paraguayan Constitution:

Whenever the State decides to transfer a state-owned company or its shares in such a company to the private sector, it will give preferential option of purchase to the workers and sectors that are directly linked with the company. A law will regulate the way in which this option will be established.

CONSTITUCiÓn DE LA REPÚBliCA DEl PARAguay [Constitution] art. 111 (Para.) [hereinafter PARA. CONST.]; see also GUISLAIN, supra note 34, at 37.

113. See Alejandro Linares \& Maristella Aldana, Privatization Laws in Colombia, LATIN Fin., Jan. 1997, at 23. See generally Cepeda, supra note 99; Luz Estella Nagle, Evolution of the Colombian Judiciary and the Constitutional Court, 6 IND. INT'L \& COMP. L. REV. 59 (1995) (discussing the evolving role of the Court).

114. Colombian Constitutional Court Decision No. C-037/94 and No. C-452/95 (on file with author).

115. See Colombia, supra note 95 , at 9 . 
national port authority, thermoelectric and hydroelectric plants, and railway interests. ${ }^{116}$

The participation of the solidarity sector in privatization has been mixed at best. Where purchases are made, it is feasible to buy only a portion of the enterprise. ${ }^{117}$ Preferred share offerings to workers' associations and cooperatives often are sold off to the highest bidder. ${ }^{118}$ In other instances, the privatization program has had, and likely will continue to have, little effect. Considering the low rates of unionization in Colombia (about eight percent), ${ }^{119}$ the poorest workers will not be organized, nor will they have the fiscal capacity to purchase shares. ${ }^{120}$

For the disciplinarians of neo-liberalism, privatization in Colombia has moved too slowly. The majority of public services continue to be delivered by the state. ${ }^{121}$ The current Pastrana Administration, though, has indicated that it will step up privatization: According to one report, the Administration is "rolling out the red carpet for foreign investors." 122 President Pastrana aims to privatize seventeen state-owned power companies and the state interest in a massive coal operation and also to partner with investors in new infrastructure development, such as roads, highways, and airports. The government estimates an anticipated \$3.1 billion U.S. dollars in revenue from privatizations in 1999 alone. ${ }^{123}$

Related to the Colombian program of privatization is the relaxation of the rules for the admission of foreign investment: Investment screening has ceased, there are few restrictions on the patriation of profits, national treatment has been granted to all foreign investors, and $100 \%$ foreign ownership is permitted in almost all sectors. ${ }^{124}$ Yet irritants to foreign investment remained in place, and they are a vestige of the notion that property performs social functions. One already has been mentioned: The constitution authorizes the state to expropriate property without the payment of compensation. ${ }^{125}$ For "reasons of equity"-a determination not reviewable by the judiciary-the legislature, authorized by an absolute majority in both chambers of Congress, may

116. See Linares \& Aldana, supra note 113, at 23.

117. In the case of the privatization of thermal electric plants, the sector was able to purchase more than a $60 \%$ interest. See id.

118. I am grateful to Professor Diego López-Medina for this point.

119. See PRS Group, Climate for Business, Nov. 1, 1996, available in LEXIS, News Library, PRS Group/IBC Market Newsletters file.

120. See Pascuzzi, supra note 94, at 476.

121. See Thomas Vogel, Colombia Woos Foreign Investors in Bid to End Economic Slump, GLOBE \& MAIL, May 31, 1999, at A11.

122. Id.

123. See id. Reports in 2000 indicate a drop in privatization revenue from $\$ 2$ billion (U.S.) to $\$ 830$ million (U.S.) and the postponement of sales in two banks, 14 electricity distributors, and Interconexion Electrica, the national electricity grid. See Recovery, of Sorts, supra note 93, at 32.

124. See Colombia-Investment Climate, InT'L MARKET InSIGHT (Nat'l Trade Data Bank, Bogota, Colombia), Aug. 13, 1996, available in LEXIS, International Trade, Company \& Financial Information, Market Reports file [hereinafter Colombia-Investment Climate.].

125. See Colom. CONST. art. 58. 
expropriate property without prior compensation. ${ }^{126}$ Another concern is that foreign investors may be precluded from participating in the divestiture of state-owned enterprises.

How might this new constitutional regime, particularly its provisions regarding privatization and the social function of property, stack up against the new investment rules regime that reflects the neo-liberal consensus on the admission and treatment of foreign investment? I turn to this question in the next part.

\section{$\mathrm{V}$}

\section{THE TRANSNATIONAL INVESTMENT RULES REGIME}

I focus here on two related instruments of transnational rule-Bilateral Investment Treaties ("BITs") and the draft Multilateral Agreement on Investment ("MAI") — and their linkages with domestic constitutional rules such as those found in the new Colombian Constitution. Privatization rules that prefer local workers or associations likely run afoul of the obligation of "national treatment" found in both investment instruments. ${ }^{127}$ National treatment requires that there be no discrimination against foreign investors resident in the other party state, so that non-resident investors are treated as if they were residents. ${ }^{128}$ The MAI, however, may have turned out to be a more tolerable instrument in this regard by permitting some exceptions to the blanket rule.

It is interesting to surmise whether national treatment obligations subvert or undermine constitutional commitments. International trade scholars have long argued that national treatment does not require any particular minimum standard of treatment, but only equality of treatment between local and foreign investors. ${ }^{129}$ States, they have argued, continue to have the ability to legislate in any area. National sovereignty, then, is not impinged in any substantive way. ${ }^{130}$ When a constitutional text authorizes or commits a state to prefer nationals, however, the national treatment rule could have the effect of negating the constitutional commitment. ${ }^{131}$ No longer is the obligation of non-discrimination simply a version of formal equality that is neutral with regard to legislative objectives. It is this constitutional context that makes the national treatment obligation cut ever "closer to the bone of national sovereignty."

126. Id.

127. See infra text accompanying notes 152-157.

128. See JOHN H. JACKSON, THE WORLD TRADING SYTEM: LAW AND POLICY OF INTERNATIONAL ECONOMIC RELATIONS 213-14 (2d ed. 1997).

129. See id. at 157.

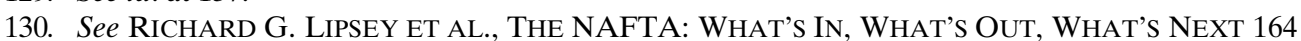
(1994).

131. See infra text accompanying notes 176-82.

132. Michael M. Hart, The Mercantilist's Lament: National Treatment and Modern Trade Negotiations, 21 J. WORLD TRADE L. 37, 55 (1987). 
The terms under which foreign investment is admitted and protected have long been an issue of controversy between the countries of the North and the South, but that controversy appears to have subsided. Codification of the rules for the protection and promotion of foreign investment is being pursued in a number of arenas. These codes establish the most stringent levels of protection favorable to foreign capital. Investment protection agreements, like the draft MAI, have emerged as a priority item for international economic law. ${ }^{133}$ An interlocking network of rules for the protection and liberalization of FDI has emerged through BITs, regional trade agreements such as NAFTA and the European Energy Charter Treaty, and at the multilateral level in the Agreement on Trade-Related Investment Measures ("TRIMs"). ${ }^{134}$ A set of non-binding investment rules was agreed to in the Asia Pacific Economic Cooperation ("APEC"), and the OECD set itself on a course of completing a multilateral agreement of which the draft MAI was the product. Taken together, these instruments of state discipline and neo-liberal principle "reflect a remarkable consensus" that the world is now safe for foreign investment. ${ }^{135}$

I have argued elsewhere that this web of economic rules, identifiable at the transnational, regional, and bilateral levels, exhibits some of the features and characteristics of domestic constitutions. ${ }^{136}$ They are a form of pre-commitment strategy that binds future generations of citizens to certain pre-determined institutional forms through which politics is practiced..$^{137}$ In addition, these economic rules, like constitutions, are difficult to amend, include binding enforcement mechanisms and judicial review, and sometimes are drawn from the very language of domestic constitutions. ${ }^{138}$

\section{A. The Bilateral Regime}

Bilateral Investment Treaties have become a commonplace tool for investment protection and promotion. The U.N. Commission on Trade and Development reports that by the end of 1998, more than 1700 BITs had been completed involving 174 countries. ${ }^{139}$ Two-thirds of these agreements were negotiated during the 1990s. ${ }^{140}$ Despite adherence to aspects of the Calvo doctrine and a rigorous commitment to the principle of national sovereignty,

133. See Michael J. Trebilcock \& Robert Howse, The Regulation of International TRADE 335-66 (2d ed. 1995).

134. See A.A. Fatouros, Towards an International Agreement on Foreign Direct Investment? 10 ICSID REV.-FOREIGN INVESTMENT L.J. 181, 188-89 (1995).

135. Antonio R. Parro, The Scope of New Investment Laws and International Instruments, in ECONOMic DeVElopment, Foreign InVESTMENT AND THE LAW 27, 31 (Robert Pritchard ed., 1996).

136. See Schneiderman, Constitutional Strictures, supra note 16, at 90.

137. See id.

138. See Schneiderman, NAFTA's Takings Rule, supra note 16, at 515.

139. See UNCTAD, WORLD INVESTMENT REPORT 1999: FOREIGN DIRECT INVESTMENT AND THE CHALLENGES OF DEVELOPMENT 117 (1999).

140. See UNCTAD, WORLD INVESTMENT REPORT 1997: TRANSNATIONAL CORPORATIONS, MARKET STRUCTURE AND COMPETITION POLICY 19 (1997). 
Latin American states increasingly have become party to agreements that incorporate stringent investment protection standards. ${ }^{141}$ At least thirty-seven BITs have been concluded between the countries of Latin America and the Caribbean. ${ }^{142}$

These agreements typically require state parties to adhere to a number of key disciplines, most of them organized around the principle of "nondiscrimination." These disciplines include national treatment, requiring treatment no less favorable than that available to nationals within the investing state, and most favored-nation ("MFN") status, mandating treatment no less favorable than that available to investors of a third country. ${ }^{143}$ In addition, there are substantive constraints on state parties including protection from expropriations and nationalizations (or measures having equivalent effect), the ability to enforce these obligations by foreign investors themselves, and mechanisms for the settlement and adjudication of disputes before international trade tribunals and domestic courts. ${ }^{144}$ These same obligations are virtually replicated in NAFTA's investment chapter. ${ }^{145}$

It is significant that investment agreements can now be enforced by foreign investors against state parties. Ordinarily, only the contracting state parties are entitled to enforce investment agreements, so that disputes are mediated through the process of inter-state diplomatic relations. Instead, the investment rules regime purports to "depoliticize" investment disputes. ${ }^{146}$ Investors are entitled to pursue litigation to enforce these agreements within the domestic court system of the contracting party, in addition to being entitled to submit disputes to binding investment arbitration. ${ }^{147}$ The parties to NAFTA were the first to assent to this type of intervention, and the practice is now reproduced in the modern BIT system. ${ }^{148}$ Kenneth Vandevelde claims that this has been "the single most important goal of the [U.S.] BIT program." ${ }^{149}$ As has been observed in Canada, this type of intervention is license for investors to meddle significantly in public policymaking within state parties. ${ }^{150}$

141. See id. at 76-77.

142. See id. at 76.

143. See JACKSON, supra note 128 , at 157.

144. See David Schneiderman, Investment Rules and the New Constitutionalism, 25 L. \& SoC. INQUIRY 757, 769 (2000).

145. See id. at 769 .

146. See Kenneth J. Vandevelde, The BIT Program: A Fifteen-Year Appraisal, in AMERICAN

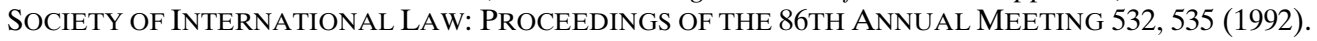

147. See id. at 532, 538. The language of Article 8 of Colombian BITs is somewhat different. See Leif Weizman, Colombia: Model Bilateral Investment Treaty of 1993, 8 INTER-AM. LEGAL MATERIALS $111,122-23$ (1998). If no settlement is achieved following three months "using the local judiciary or any other means," the parties may submit the dispute to the "administrative courts or tribunals" of one of the parties or to arbitration or conciliation with the International Center for the Settlement of Investment Disputes ("ICSID"). Id. at 123.

148. See Vandevelde, supra note 146, at 534.

149. $I d$.

150. See generally Schneiderman, Constitutonal Strictures, supra note 16. 
Parties to these agreements are entitled to list reservations, or carve-outs, for those sectors that will be exempt from the requirement of national treatment and MFN status, and there are general exceptions that typically concern such matters as national security, public order, and protection of the environment. ${ }^{151}$ Ordinarily, no reservations or exceptions are permitted with regard to expropriations and nationalizations-these are viewed as simply beyond the pale.

BITs usually do not contain express provisions regarding processes for the divestiture of state enterprises. Typically, BIT obligations are not triggered until a foreign investor enters the host state and, in order to enter that jurisdictional space, investors must comply with all the usual laws or regulations. $^{152}$ The sale of public assets to private owners-the process of denationalization-will not ordinarily activate the national treatment obligation of non-discrimination against foreign investors unless the non-resident investor has entered the jurisdictional space of the host state. In other words, privatization schemes that impinge on foreign investor participation will not offend the national treatment rule unless the investor already is established in the country.

The OECD considered this question in 1991, asking whether the principle of national treatment, as defined in its 1976 standard investment code, should apply to the "privatisation of enterprises previously under public ownership." The OECD concluded that the undertaking should come into play whenever areas

previously under monopoly are opened up. In such cases, access to move into these areas should then be provided on a non-discriminatory basis as between private domestic and foreign-controlled enterprises already established in the country in question. If restrictions prohibit or impede in any way the participation of foreigncontrolled enterprises vis-à-vis their domestic counterparts, then these restrictions are to be reported as exceptions to National Treatment. The objective of the instrument in this context is, therefore, to ensure access to formerly closed sectors on an equal basis. $^{154}$

Would the constitutionally mandated privatization rule in Colombia, which requires preferential share offerings to employees, trade unions, and cooperatives, offend the principle of national treatment for those investors already established within Colombia? Leaving aside the problematic question of applying an equal rights analysis to frustrate the achievement of rational economic and political objectives ${ }^{155}$ the answer turns on the way in which one classifies the commitment. One option is to classify the rule as outlawing

151. See Ibrahim F.I. Shihata, Recent Trends Relating to Entry of Foreign Direct Investment, 9 ICSID REV.-FOREIGN INVESTMENT L.J. 47, 52, (1994). In the case of NAFTA, Mexico listed as nonconforming measures numerous activities protected by the Calvo Clause. See id. at 61.

152. See M. Sornarajah, THE InTERnAtional LAW On ForEIGN INVESTMENT 85 (1994).

153. Organisation for Econ. Coop. and Dev., Main Features of the Multilateral Agreement on Investment 7 (1991) (unpublished paper, on file with author).

154. Id. (emphasis added)

155. See SORNARAJAH, supra note 152 , at 85 . 
foreign investment participation and therefore discriminatory on the ground of nationality. Another is to classify the rule as preferring one economic sector over other sectors, such as employers or other potential local investors, and therefore discriminatory on the ground of employment status or some other such ground, but not on the ground of nationality. Yet another option is to consider the rule as preferring local employee and associational investors over foreign employee and other associational investors, resulting in discriminatory treatment. The first and broadest interpretation is the one adopted by the United States, as well as many international trade scholars. It would outlaw any measures that "have the intent or the effect of preventing or significantly impeding inward direct investment by non-residents." 156 According to this standard, and even according to the less broad third option, preferred share offerings to the solidarity sector likely would be inconsistent with the principle of national treatment, requiring that foreign investors be treated no less favorably than domestic enterprises and investors. The draft MAI text of April 1998 helps to shed light on this question. According to the negotiating parties, any preferential scheme would have been contrary to the broadly drafted national treatment rule. ${ }^{157}$

This understanding of the BIT rules suggests that the constitutionally mandated privatization rule in Colombia, which requires preferential share offerings to employees, trade unions, and cooperatives, will offend the principle of national treatment for those investors already established within Colombia. Preferred share offerings to this sector run contrary to the principle of national treatment.

Before turning to the MAI, it should be mentioned that U.S. bilateral investment treaty standards, which are incorporated increasingly into Canadian BITs, are more stringent and would increase the likelihood of conflict with the domestic constitutional regime. ${ }^{158}$ These standards require non-discrimination in the admission or establishment of investments, not merely fair treatment after admission. ${ }^{159}$ Those non-resident foreign investors who merely wish to establish a presence in the host country are entitled to equal treatment with domestic nationals even before they make any investment. Colombian constitutional requirements undoubtedly would be in conflict with this more stringent standard.

As discussed below, the Colombian Constitutional Court has shown itself to be somewhat resistant to the strictures of economic globalization. It is likely, then, that these BITs would not survive constitutional scrutiny insofar as they de-activate the constitutional obligations concerning privatization. But the material result likely would be that the Colombian government would not resist

156. Hart, supra note 132 , at 54.

157. See infra text accompanying notes 164-165.

158. See Sornorajah, supra note 152 , at 245.

159. See UNCTAD, supra note 139 , at 77 . In this way, Canadian BIT practice has ceased to be modeled after British practice. See Robert K. PATERSOn ET AL., InTERnATIONAL TRADE AND INVESTMENT LAW IN CANADA 12-18 (1994). 
those demands; it would submit to the disciplines of the investment rules regime by seeking an amendment to the Colombian Constitution.

B. The Multilateral Regime

How might Colombian constitutional rules fare against the terms of the draft Multilateral Agreement on Investment? The twenty-nine member countries of the OECD undertook the task of completing an enforceable agreement for the protection and promotion of foreign investment in September 1995. It was not that investment flows between these countries had been frustrated; rather, the objective was to set very high standards for the protection of investment that countries in the so-called "developing" world would be pressured to adopt. ${ }^{160}$ The web of bilateral agreements then could be filled in by this new multilateral instrument.

Negotiations in Paris came to a halt, in part, because of resistance to the agreement in the United States Congress, the withdrawal of France from the negotiating table, and the coordinated action of citizen organizations in Canada, France, New Zealand, and elsewhere. ${ }^{161}$ While there is little likelihood that the exercise will continue at the OECD, it is probable that negotiations will shift to other venues, like the World Trade Organization. It is worthwhile, then, to review the provisions of the MAI as they concern privatization, particularly as the draft text contains provisions that expressly contemplate rules for the treatment of foreign investors in the case of a divestiture of state assets-a proposal the OECD review had recommended back in $1991 .^{162}$

Although a number of key issues were resolved in negotiations, it is interesting that the draft provisions concerning privatization are among the least settled. ${ }^{163}$ In fact, the provisions concerning privatization suggest substantial disagreement between some of the negotiating parties. If the draft text signals what remained in dispute at the OECD negotiations, it also makes difficult drawing any definitive conclusions about what consensus would have emerged on this issue among the negotiating parties.

A number of matters were not in dispute, however. Because national treatment and MFN treatment would be accorded to investors in the establishment phase under Article III-the United States BIT standardprocesses of privatization would ordinarily be caught by the rule. But the parties felt it desirable to spell out how these obligations applied in the privatization context. It was settled that the privatization discipline in the MAI

160. See JANe Kelsey, Reclaiming the Future: NeW ZEALAND AND THE GLOBAL ECONOMY 321 (1999).

161. See William A. Dymond, The MAI: A Sad and Melancholy Tale in CANADA AmONG NATIONS 1999: A Big League Player? 25-53 (Fen Osler Hampson et al. eds., 1999); Paul Vallely, How the Web Saved the World, INDEP. (LONDON), Jan. 10, 1999, at 1.

162. See Organisation for Econ. Coop. and Dev., supra note 153.

163. For a discussion of the issues that remained unresolved, including the nature of exceptions, the treatment of culture, the coverage of subnational government, and labor and environment issues, see Dymond, supra note 161, at 34. 
would require that national treatment and MFN status be accorded to all manner of privatization "irrespective of the method of privatization chosen," such as public offering or direct sale, and to all phases of the process. ${ }^{164}$ In dispute was the extent to which "special share arrangements," such as management/employee buy-outs, "golden shares," which are those reserved for government, and special schemes for the public, offended national treatment and MFN treatment. ${ }^{165}$

It was agreed that these arrangements prima facie offended the principle of non-discrimination; disagreement turned on the manner in which this was to be acknowledged in the text. Most delegations appeared willing to exempt special share arrangements, adopting the more restrictive definition of national treatment: So long as foreign investors are treated no less favorably than other excluded domestic investors, there is no discrimination. ${ }^{166}$ Others preferred that the obligation of non-discrimination remain in effect, but that those states concerned about privatization in certain areas designate as reservations to the agreement special share arrangements in those sectors. ${ }^{167}$

The proposed text accepted by a large number of delegations would have considered special share arrangements compatible with the commitment to national treatment and MFN treatment unless they expressly offended MFN status or discriminated against investments on the grounds of "nationality or permanent residency." 168 The explanation provided by the OECD predating the April 1998 draft text is that so long as foreign investors "are not put in a more disadvantageous position than domestic investors which do not qualify for such privatisation schemes," these measures will be considered non-discriminatory. ${ }^{169}$ Taking this interpretive clause into consideration, it may have been that, in the case of the multilateral instrument, in contrast to the BIT rules, a comprehensive code would have provided clarity for preferred share options for employees and their associations. In an environment where political alternatives are so constrained, this could have been considered the preferred alternative to an unlimited BIT national treatment rule.

A minority of delegations preferred the option of designating certain sectors as exceptions. Exempting privatization processes from MAI disciplines could also have avoided constitutional conflict. In large measure, this would have

164. "[F]our delegations reserved their position on all privatisation obligations." ORGANISATION FOR ECON. COOP. AND DEV., THE MAI NEGOTIATING TEXT 27 n.41 (1998).

165. This is the language of the draft negotiating text at II 3, altern. 4, art. 7. See id. at 29; ANDERS AHNLID, NEW DisCIPLINES 23, 24 (OECD Working Papers, Proceedings of the Special Session on the Multilateral Inv. Agreement, Vol. V, No. 96, 23, 24 (1997)).

166. See AHNLID, supra note 165, at 24; MADALENA OlIVEIRA ESILVA, PRIVATISATION AND Monopolies 33, 35 (OECD Working Papers, Multilateral Agreement on Inv. State of Play, Vol. V, No. 51 (1997)).

167. See AHNLID, supra note 165, at 24; ESILVA, supra note 166.

168. This was the language "supported by a large number of delegations." See Organisation for Econ. Coop. and Dev., supra note 153, at 28 (concerning II 3, altern. 1, art. 4).

169. Organisation for Econ. Coop. and Dev., supra note 153, at 7. It is not clear whether both intentional and unintentional discrimination would be exempted. See ESILVA, supra note 166, at 33. 
depended on the specificity of those reservations: Whether they were bound (in which case no new sectors could be added) or unbound (in which the reservations anticipated future sectoral exceptions). ${ }^{170}$ The expectations of the MAI negotiators was that the agreement would "standstill" investment measures: The agreement would provide an "irreversible minimum standard" from which states could not deviate. ${ }^{171}$ The agreement also would "rollback" reservations and exceptions, "with a view to their eventual elimination," according to a predetermined timetable, for instance. ${ }^{172}$ Over time, then, even a list of exempted enterprises or sectors would be subject to erosion due to commitments in the MAI text or state peer pressure.

\section{VI \\ CONCLUSION}

The state capitalist model of constitutional design has not only fallen into disfavor, it is facing near-permanent erasure from the effects of the neo-liberal model represented by the investment rules regime. Though the draft MAI suggests a more tolerable approach to alternatives to privatization, we should remember that preferred share option schemes remain inconsistent with the key precepts of the investment rules regime and that these disciplines were intended to tighten their grip over time, so that no exceptions would be permissible.

Admittedly, the conflict outlined above is not confined to the arena of constitutional analysis. It has resonance in the context of ordinary legislative rules for the privatization of state enterprise. But the constitutional context heightens the quality of the conflict. Constitutions are intended to have a level of fixity outside of politics, that is, they are intended to standardize the enduring rules of the game. As such, they should be able to withstand the pressures generated by particular class interests within states and by the material interests of other states. But constitutions also are within politics, and so provide a focal point of real conflict about alternative futures. Constitutions, to state the obvious, both shape politics and are shaped by politics. ${ }^{173}$

This conflict is being felt in Colombia, where the expropriation rule in the Colombian Constitution came into direct conflict with the investment rules regime. The 1994 Colombian-United Kingdom BIT contained the usual provisions concerning national treatment, MFN treatment, and prohibitions on expropriations and nationalizations. ${ }^{174}$ Expropriation and nationalization are prohibited unless they are for a public purpose, non-discriminatory, and accompanied by the payment of "prompt, adequate and effective

170. See BARry ApPleton, NAVigating NAFTA 161 (1994).

171. William H. Witherell, The OECD Multilateral Agreement on Investment, 4 TRANSNAT'L. CORP. 1, 11 (1995).

172. Id.

173. See John Dearlove, Bringing the Constitution Back In: Political Science and the State, 37 PoL. STUD. 521, 534 (1989).

174. See Bilateral Investment Treaty, Mar. 9, 1994, Col.-U.K.; Weizman, supra note 147, at 116. 
compensation" that is fully realizable and transferable. This stringent standard of compensation, the "Hull formula," has been held up by the United States as the standard required by international law. The BIT as enacted by Law 246/95 was presented to the Colombian Constitutional Court for its certification-a constitutional requirement in Colombia. ${ }^{175}$

The Court held, by a six-to-three majority, that the BIT was contrary to the Colombian Constitution in two respects. ${ }^{176}$ First, the BIT had the effect of deactivating provisions of the Colombian Constitution, such as expropriation without the payment of compensation in the interests of equity. The Government could not waive the exercise of a power delegated to it by the Constitution by conceding the payment of prompt, adequate, and effective compensation. Second, the investment treaty offended the equality provisions of the constitution by granting to citizens of British nationality preferential treatment with respect to expropriations, which was not available even to Colombian nationals. In other words, the BIT offended Calvo's edict that foreign nationals not be entitled to preferential treatment over domestic nationals. ${ }^{177}$ The Court reached a similar conclusion in regard to a CubaColombia BIT. ${ }^{178}$

The Colombian government, anxious to reassure foreign investors that Colombia is open to foreign investment, pledged to remove this remnant of a bygone era, though no government in modern Colombian history has expropriated foreign property, nor have investors expressed any concern that the risk of expropriation is high in Colombia. ${ }^{179}$ Moreover, there is some doubt that any benefits will accrue to Colombia as a consequence. ${ }^{180}$ A recent U.N. study confirms that investment protection agreements are relatively insignificant in determining amounts of Foreign Direct Investment ("FDI"). ${ }^{181}$ Other factors, including market size and growth, exchange rates, and country risks, are more important determinants of FDI. ${ }^{182}$ Nonetheless, the Colombian government was intent on removing the offending language from the Constitution, deploying investment policy and constitutional reform to "symbolize a commitment to economic liberalism."183 Two paragraphs of constitutional text were repealed in August 1999; the constitutional property

175. See ColOM. CONST. art. 241, no. 10.

176. See Colombian Constitutional Court Decision No. C-358/96 (on file with author).

177. See Weizman, supra note 147 , at 116 . One solution is to confer the same advantages on domestic nationals (though this may not satisfy the constitutional requirement) or, alternatively, on all investors regardless of nationality. According to Vandevelde, the latter option would "ensure genuine investment neutrality and create a host state constituency in support of an enduring liberal investment regime." Kenneth J. Vandevelde, The Political Economy of a Bilateral Investment Treaty, 92 AM. J. INT'L L. 621, 639 (1998).

178. Colombian Constitutional Court Decision No. C-379/96 (on file with author).

179. See Colombia-Investment Climate, supra note 124.

180. See SORNARAJAH, supra note 152, at 235-36.

181. See UNCTAD, BILATERAL INVESTMENT TREATIES IN THE MID-1990s, at 117 (1998).

182. See id.

183. Vandevelde, supra note 146, at 628. 
clause no longer permits expropriation without the payment of compensation. ${ }^{184}$ Here is a clear instance of neo-liberal constitutionalism disciplining domestic constitutional text: Interference with private property and investment rights simply is beyond the bounds of acceptability.

Terence Daintith and Monica Sah suggest that constitutions can be "economically neutral," in terms of not expressing any preference for a given system of economic relations within the state, whether public or private. ${ }^{185}$ Perhaps removing constitutional constraints to privatization would be preferable to formal expressions of ideological precommitment. Yet the constitution-like rules that operate outside the domestic state in the transnational arena pose real constraints on domestic constitutionalism. The investment rules regime-the web of interlocking rules and structures that constrain through the force of law state treatment of foreign investment-tilts the table in favor of foreign investors. If the democratization of property and the redistribution of state assets to a wide stratum of the population are considered discriminatory, then the economic chapter of the transnational constitution is not neutral. Rather, states are bound for the foreseeable future to organize public policy in favour of the neo-liberal model.

In this environment, are domestic constitutions a reasonable resource to countervail the investment rules regime? We should keep in mind that states are the authors of this regime that limits their capacity to regulate privatizations and to intervene in the marketplace. So rather than seek to constrain state action further through constitutional limits, perhaps the better option is to loosen these binding precommitments. States perhaps should unlock themselves from the regime of investment rules, though this would be a difficult matter because most BITs remain in force for periods of up to ten years for those investments established during the time a treaty was in force. The draft MAI would have locked states into at least a twenty-year commitment. ${ }^{186}$

The failed MAI talks, though, should hearten those who wish to free states from a predetermined constitutional course of economic conduct. By removing themselves from the table, the French delegation was able effectively to scuttle negotiations. So rather than bypassing the state, one should better understand the ways in which states are implicated in the structuring of the investment rules

184. The amendment, by Acto Legislativo 1/99 of Aug. 4, 1999, excised the provisions concerning equitable expropriation:

Con todo, el legislador, por razones de equidad, podrá determinar los casos en que no haya lugar al pago de indemnización, mediante el voto favorable de la mayoría absoluta de los miembros de una y otra Cámara. Las razones de equidad, así como los motivos de utilidad pública o de interés social, invocados por el legislador, no serán controvertibles judicialmente [trans: Still, the legislative, for reasons of equity, may determine those cases in which there is no ground for indemnification through an affirmative vote of the absolute majority vote of the members of both chambers. Reasons of equity, as well as motives of public necessity or social interest invoked by the legislative, will not be judicially reviewable.].

Id. (translation by Moira Gracey).

185. Daintith \& Sah, supra note 71 , at 465.

186. See Schneiderman, NAFTA's Takings Rule, supra note 16. 
regime. Citizens, then, can aim to undo constraints, both domestic and transnational, on the democratization of property and the promotion of selfrule. 